\title{
Morphometric Study of Glenoid Cavity of Human Scapula in Central India
}

\author{
Preeti Prabhakarrao Thute ${ }^{1}$, Harsha Atul Keche², Darshna Gulabrao Fulmali³ \\ ${ }^{1}$ Department of Anatomy, Jawaharlal Nehru Medical College, Sawangi Meghe, Wardha, Maharashtra, India. \\ 2Department of Anatomy, Jawaharlal Nehru Medical College, Sawangi Meghe, Wardha, Maharashtra, India. \\ ${ }^{3}$ Department of Anatomy, Jawaharlal Nehru Medical College, Sawangi Meghe, Wardha, Maharashtra, India.
}

\section{ABSTRACT}

\section{BACKGROUND}

Deep knowledge of the shape and dimensions of the glenoid, and variations in normal anatomy of glenoid, are important in the design and fitting of glenoid component in total shoulder arthroplasty. It is also essential while dealing with the pathological conditions like osseous Bankart lesion, osteochondral defects, etc.

\section{METHODS}

The cross-sectional study was carried out on 122 undamaged dry adult human scapulae. Out of these 122 scapulae, 62 belonged to right side and 60 belonged to left side. Parameters studied were Maximum Scapular Length, Maximum Scapular Breadth, Vertical Glenoid Diameter (VGD), Transverse Glenoid Diameter I (TGD I), Transverse Glenoid Diameter II (TGD II) and Shape of the glenoid cavity.

\section{RESULTS}

The mean maximum scapular length observed was $140.77 \pm 8.19 \mathrm{~mm}$ on right and $142.30 \pm 7.99$; the mean maximum scapular breadth was $100.70 \pm 7.70 \mathrm{~mm}$ on right side and $99.88 \pm 5.57 \mathrm{~mm}$ on the left; the mean vertical glenoid diameter was $36.09 \pm$ $2.52 \mathrm{~mm}$ on the right and $36.40 \pm 1.86 \mathrm{~mm}$ on the left side; the mean transverse glenoid diameter I (TGD I) was $24.40 \pm 3.67 \mathrm{~mm}$ on the right side and $23.57 \pm 3.41$ $\mathrm{mm}$ on the left side; the mean transverse glenoid diameter II (TGD II) was $16.02 \pm$ $2.94 \mathrm{~mm}$ on the right side and $16.37 \pm 3.35 \mathrm{~mm}$ on the left side. In all the measurements bilateral differences were not statistically significant ( $p$ values $>0.05$ ). The most common shape of glenoid cavity recorded in the present study was pear shape $(50.82 \%)$ followed by inverted comma shape $(36.89 \%)$. The least common shape was oval (12.30\%).

\section{CONCLUSIONS}

The parameters studied were with minimal regional differences when compared to those of other authors in India except that in shape which definitely differs from others.

\section{KEY WORDS}

Arthroplasty, Glenoid Notch, Instability, Glenoid Component, Central India
Corresponding Author: Dr. Harsha Atul Keche, C/o. Kavita Ajit Luniya, House No. 459, Ward No. 4, Patil Nagar, Wardha-442001, Maharashtra, India.

E-mail: drharshakeche@rediffmail.com

DOI: $10.14260 / j e m d s / 2020 / 508$

How to Cite This Article:

Thute PP, Keche HA, Fulmali DG. Morphometric study of glenoid cavity of human scapula in central India. J Evolution Med Dent Sci 2020;9(33):2340-2344, DOI: 10.14260/jemds/2020/508

Submission 16-05-2020,

Peer Review 10-07-2020,

Acceptance 16-07-2020,

Published 17-08-2020.

Copyright (c) 2020 JEMDS. This is an open access article distributed under Creative Commons Attribution License [Attribution 4.0 International (CC BY 4.0)] 


\section{BACKGROUND}

Scapula a large, flat, triangular bone that lies on the posterior chest wall between the level of second and seventh ribs. It has two surfaces, three borders and three angles. The three angles are medial, inferior \& lateral. The lateral angle is truncated \& broad which is considered as head of scapula. It has shallow glenoid cavity which provides socket for head of humerus to form shoulder joint. It is pyriform in shape, narrower above as compared to lower part. ${ }^{1}$ Glenoid cavity is connected to the plate like body by an anatomical neck which is most distinct at its dorsal and inferior aspects. ${ }^{2}$

The glenoid cavity shows variable morphology. There is a notch present on its anterosuperior part i.e. on the anterior glenoid rim which gives its different shape. ${ }^{3,4}$

According to Fick et al the glenoid notch is situated somewhat above the middle of the anterior margin of the cavity and can be very prominent, very shallow or absent. When the notch is present the shape of the cavity can be described as pear shaped or inverted comma shaped. When it is absent the cavity is round or oval shaped. 5

The glenoid margin provides attachment to glenoid labrum, a fibro-cartilaginous rim except at the supra-glenoid tubercle. The glenoid labrum makes the glenoid cavity deep for the head of humerus. The fibrous capsule of shoulder joint is attached around the periphery of glenoid cavity outside the labrum, so it includes supraglenoid tubercle but excludes the infraglenoid tubercle. The laxity of fibrous capsule and shallow glenoid cavity provides great range of mobility to the joint, but loses its stability. The stability of the joint is maintained by various factors such as coraco-acromial arch, glenoid labrum and musculotendinous cuff. Most frequently shoulder joint is dislocated inferiorly as it is having less support in this region. ${ }^{6}$

Dislocation of joint is mostly associated with the fracture of glenoid cavity. For the management of such injuries, prosthesis, arthroplasty and rotator cuff tear repairs are frequently required. The treatment of choice also includes total shoulder replacement.7-9

Knowledge of the shape and dimensions of the glenoid cavity are important in the design and fitting of glenoid component for total shoulder arthroplasty. So deep understanding of variations in normal anatomy of glenoid cavity is essential while dealing with the pathological conditions like osseous Bankart lesion and osteochondral defects. ${ }^{10}$

The present study was carried out with objective to obtain complete morphometric data about the glenoid cavity specifically the diameters and various shapes of glenoid cavity of the population of Central India to compare with other studies.

\section{METHODS}

The present study is a cross sectional study which has been carried out on 122 undamaged dry adult human scapulae, which were collected from the different students of the 1st year MBBS and Department of Anatomy, Jawaharlal Nehru
Medical College, Sawangi (Meghe). Out of these 122 scapulae, 62 belong to right side and 60 belong to left side.

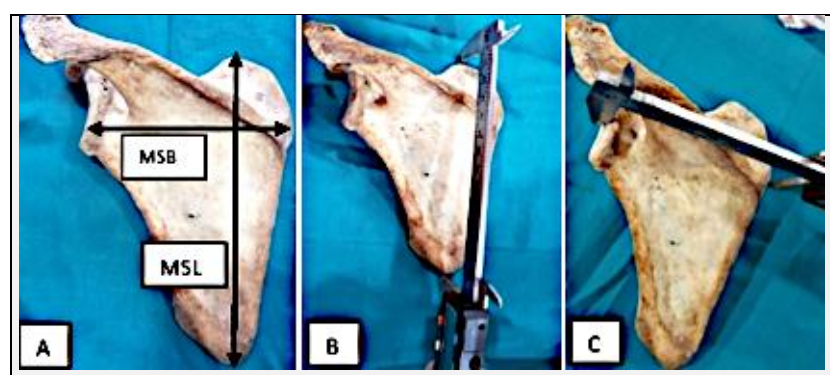

Figure 1. A. Double Arrow Showing Maximum Scapular Length (MSL) and Maximum Scapular Breadth (MSB), B. Measurement of Maximum Scapular Length (MSL) by Vernier Caliper, C. Measurement of Maximum Scapular Breadth (MSB) by Vernier Caliper

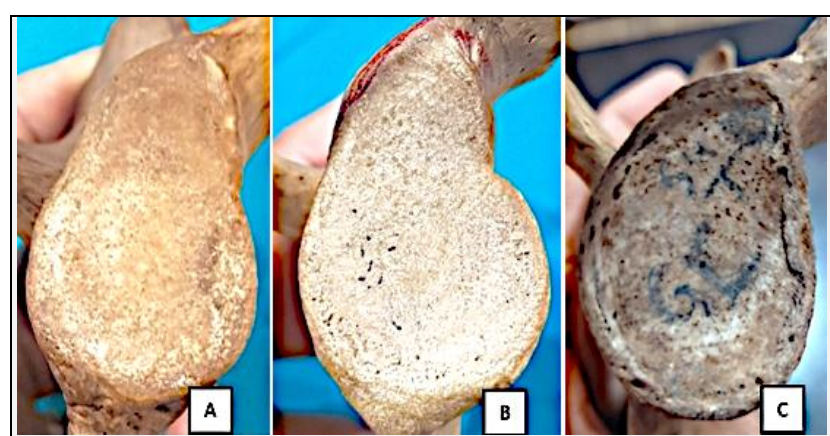

Figure 2. Different Shapes of Glenoid Cavity A. Pear Shaped, B. Inverted Coma Shaped, C. Oval.

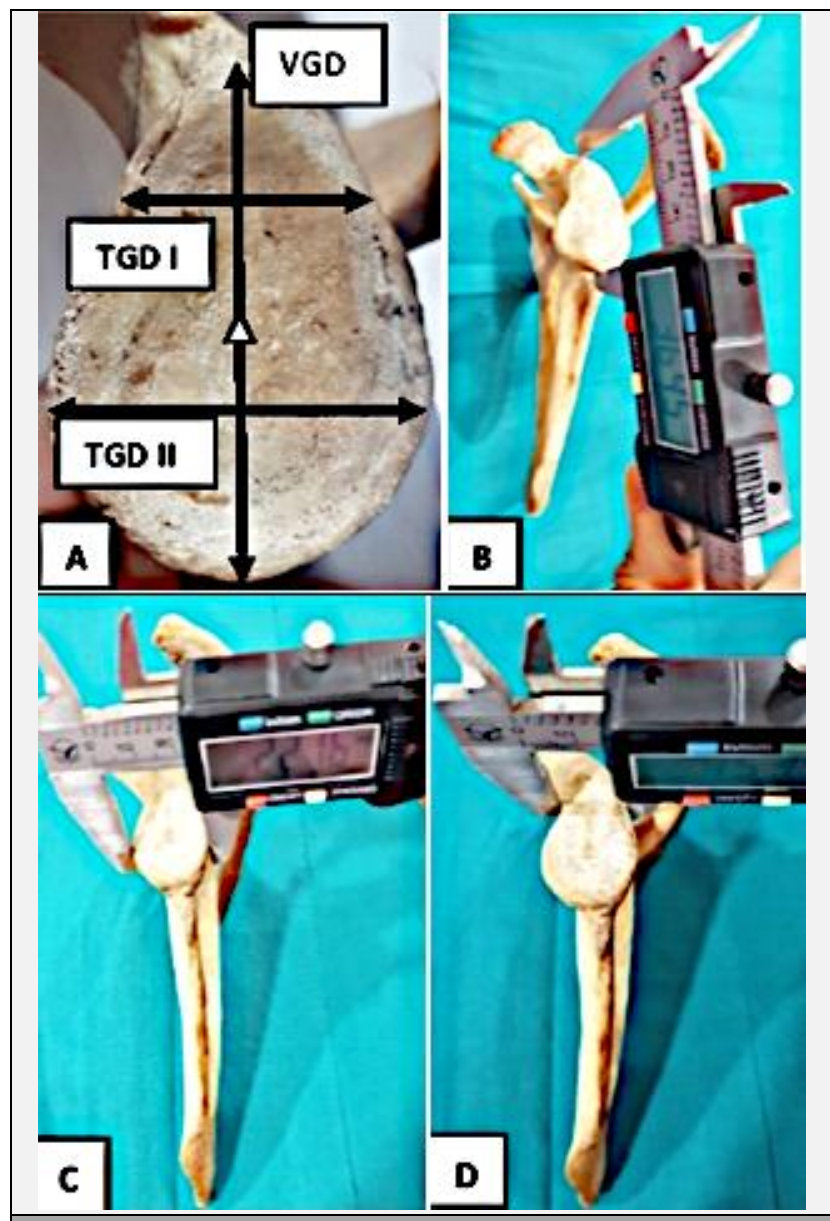

Figure 3. A. Various Diameters of Glenoid Cavity, B. Vertical Glenoid Diameter (VGD), C. Transverse Glenoid Diameter-I, (TGD-I), D. Transverse Glenoid Diameter-II (TGD-II) 
Only those scapulae which are fully ossified, dried, macerated, clean and well demarcated are included in this study. While those with damage in the glenoid cavity or with any obvious pathology are excluded from this study. All parameters are measured by Digital Vernier caliper and are recorded in millimetres only. The following parameters of the glenoid cavity were studied-

\section{Maximum Scapular Length (MSL)}

Maximum distance between the summit of superior and inferior angle respectively. (Fig. 1)

\section{Maximum Scapular Breadth (MSB)}

Maximum distance from the root of the spine on the medial border and at the middle of the posterior border of glenoid cavity. (Fig. 1)

\section{Vertical Glenoid Diameter (VGD)}

Maximum distance between the most prominent point on the supra-glenoid tubercle to the inferior margin of the glenoid cavity. (Fig. 1)

\section{Transverse Glenoid Diameter I (TGD I)}

It is the maximum breadth of the articular margin of the glenoid cavity perpendicular to the glenoid cavity height. (Fig. 3)

\section{Transverse Glenoid Diameter II (TGD II)}

It is the antero-posterior diameter of the top half of the glenoid cavity at the mid -point between the superior rim and the mid-equator. Shape of the glenoid cavity: Shape made by the slightly raised rim of the glenoid cavity. (Fig. 3)

\section{Shape of the Glenoid Cavity}

The shape of the glenoid cavity was taken by tracing of slightly raised rim of the glenoid cavity on a white paper with the help of a lead pencil. Three types of glenoid were observed: (a) Pear shaped (b) Inverted comma shaped and (c) Oval shaped. (Fig. 2)

\section{Statistical Analysis}

Statistical analysis was done by using descriptive and inferential statistics using chi square test and z-test for difference between two mean and software used in the analysis were SPSS 24.0 version and GraphPad Prism 7.0 version and $\mathrm{p}<0.05$ is considered as level of significance.

\section{RESULTS}

This study was carried out on 122 dry scapulae. The mean maximum scapular length was observed as $140.77 \pm 8.19 \mathrm{~mm}$ in right and $142.30 \pm 7$ in left scapulae, the mean maximum scapular breadth was $100.70 \pm 7.70 \mathrm{~mm}$ and $99.88 \pm 5.57 \mathrm{~mm}$ on right and left scapulae respectively, the mean vertical glenoid diameter was $36.09 \pm 2.52 \mathrm{~mm}$ on right and $36.40 \pm$ $1.86 \mathrm{~mm}$ on left side, the mean Transverse glenoid diameter I (TGD I) was $24.40 \pm 3.67 \mathrm{~mm}$ on right side and $23.57 \pm 3.41$ mm on left side, the mean Transverse glenoid diameter II (TGD
II) was $16.02 \pm 2.94 \mathrm{~mm}$ on right side and $16.37 \pm 3.35 \mathrm{~mm}$ on left side. The most common shape of glenoid cavity recorded in the present study was pear shape $(50.82 \%)$ followed by inverted comma shape (36.89\%). The least common shape was oval (12.30\%). In all the above measurements bilateral differences was not statistically significant $(\mathrm{P}$ values $>0.05$ ) (Table $1 \& 2$ ).

\begin{tabular}{|c|c|c|c|c|c|}
\hline Parameters & & Mean & S.D. & $\begin{array}{l}\text { Std. Error } \\
\text { Mean }\end{array}$ & z-Value \\
\hline \multirow{2}{*}{$\begin{array}{l}\text { Maximum Scapular } \\
\text { Length (MSL) }\end{array}$} & Right & 140.77 & 8.19 & 1.04 & 1.03 \\
\hline & Left & 142.30 & 7.99 & 1.03 & $\mathrm{p}=0.30, \mathrm{NS}$ \\
\hline \multirow{2}{*}{ Breadth of scapula } & Right & 100.70 & 7.70 & 0.97 & 0.67 \\
\hline & Left & 99.88 & 5.57 & 0.71 & $\mathrm{p}=0.50, \mathrm{NS}$ \\
\hline Vertical Glenoid & Right & 24.40 & 3.67 & 0.46 & 1.29 \\
\hline Diam & Left & 23.57 & 3.41 & 0.44 & $\mathrm{p}=0.19, \mathrm{NS}$ \\
\hline Transverse Glenoid & Right & 16.02 & 2.94 & 0.37 & 0.61 \\
\hline Diameter-I (TGD I) & Left & 23.57 & 3.41 & 0.44 & $\mathrm{p}=0.53, \mathrm{NS}$ \\
\hline Transverse Glenoid & Right & 16.02 & 2.94 & 0.37 & 0.61 \\
\hline Diameter-II (TGD II) & Left & 16.37 & 3.35 & 0.43 & $\mathrm{p}=0.53, \mathrm{NS}$ \\
\hline
\end{tabular}

\begin{tabular}{|ccccc|}
\hline Shape of Glenoid & Right Side & Left Side & Total & \multirow{2}{*}{ 2-Value } \\
Pear Shaped & $32(51.61 \%)$ & $30(50 \%)$ & $62(50.82 \%)$ & \\
Inverted Comma & $21(33.87 \%)$ & $24(40 \%)$ & $45(36.89 \%)$ & 0.83 \\
Oval & $9(14.52 \%)$ & $6(10 \%)$ & $15(12.30 \%)$ & $\mathrm{p}=0.66, \mathrm{NS}$ \\
Total & $\mathbf{6 2}(\mathbf{1 0 0} \%)$ & $\mathbf{6 0}(\mathbf{1 0 0} \%)$ & $\mathbf{1 2 2}(\mathbf{1 0 0} \%)$ & \\
\hline \multicolumn{4}{|c|}{ Table 2. Comparison of Shape of Glenoid in Right and Left Side } \\
\hline
\end{tabular}

\section{DISCUSSION}

Many anatomists, orthopaedic surgeons and researchers worked to determine the glenoid diameters in different populations by direct measurements of dry scapula, radiological measurement of scapula or radiographic measurements in living patients. All researchers worked in a similar way. The present study was undertaken to search for any similarity or difference with respect to the measurements of the glenoid cavity.

\section{Maximum Scapular Length (MSL)}

In present study the mean maximum scapular length was observed to be $140.77 \pm 8.19 \mathrm{~mm}$ and $142.307 .99 \mathrm{~mm}$ in right and left scapulae respectively, very nearer to the values obtained by Singal et al ${ }^{11}$ and Krishnaiah et al ${ }^{12}$ However our findings were quite different when compared to the Population variation may be the cause for these differences. The mean scapular length observed by Akhtar MJ et al ${ }^{13}$ was $135.07 \pm 14.23 \mathrm{~mm}$ and by Patel et $\mathrm{al}^{14}$ in Gujarati population was $136.03 \pm 11.49 \mathrm{~mm}$ in male scapulae and $119.63 \pm 8.81$ $\mathrm{mm}$ in female scapulae. The studies by Flower $\mathrm{WH}^{15}$, Coskun et $\mathrm{al}^{16}$, Wael Amin NED et $\mathrm{al}^{17}$ on European, Turkish and Egyptian population respectively higher mean maximum scapular lengths than those of the present study. (Table 3)

\section{Maximum Scapular Breadth (MSB)}

The mean maximum breadth of scapula observed in the present study was $100.70 \pm 7.70 \mathrm{~mm}$ which is very nearer to the values obtained by Flower $\mathrm{W} \mathrm{H}^{15}$ whose reported mean Maximum Scapular breadth was $101.42 \mathrm{~mm}$ and that by Patel et $\mathrm{al}^{14}$ was $100.67 \pm 8.51 \mathrm{~mm}$ in males. Singal et $\mathrm{al}^{11}$ and Akhtar MJ et al $^{13}$ in found a mean maximum scapular breadth of 96.4 $\pm 7 \mathrm{~mm}$ and $97.55 \pm 9.63 \mathrm{~mm}$ respectively which is lower than the present study. Patel et al also reported mean breadth of 
scapula were $93.52 \pm 4.38 \mathrm{~mm}$ in female scapulae. While higher values were reported by Krishnaiah et al,12 Flower WH, ${ }^{15}$ Wael Amin NED et al ${ }^{17}$ in their studies. (Table 3)

\begin{tabular}{|c|c|c|c|}
\hline Researcher & $\begin{array}{l}\text { Sample } \\
\text { Size }\end{array}$ & $\begin{array}{c}\text { Mean Maximum } \\
\text { Scapular Length } \\
(\mathrm{mm})\end{array}$ & $\begin{array}{c}\text { Mean Maximum } \\
\text { Scapular Breadth } \\
(\mathrm{mm})\end{array}$ \\
\hline Flower $\mathrm{W} \mathrm{H}^{15}$ & 200 & 155.54 & 101.42 \\
\hline Coskun et al ${ }^{16}$ & 90 & $98.8 \pm 7$ & - \\
\hline Patel et al ${ }^{14}$ & Male: 40 & $136.03 \pm 11.49$ & $\begin{array}{c}100.67 \pm 8.51 \\
93.52+4.38\end{array}$ \\
\hline Singal et $\mathrm{al}^{11}$ & 162 & $141.7 \pm 8.9$ & $\begin{array}{c}93.52 \pm 4.38 \\
96.4 \pm 7\end{array}$ \\
\hline Krishnaiah et $\mathrm{al}^{12}$ & 50 & $143.27 \pm 11.44$ & $105.6 \pm 5.08$ \\
\hline Wael Amin NED et $a^{17}$ & 160 & $151.16 \pm 10.32$ & $107.22 \pm 9.74$ \\
\hline Akhtar MJ et al ${ }^{13}$ & 228 & $135.07 \pm 14.23$ & $97.55 \pm 9.63$ \\
\hline Present study & $\begin{array}{l}\text { Right: } 62 \\
\text { Left: } 60\end{array}$ & $\begin{array}{l}140.77 \pm 8.19 \\
142.30 \pm 7.99\end{array}$ & $\begin{array}{c}100.70 \pm 7.70 \\
99.88 \pm 5.57\end{array}$ \\
\hline 7 & arisol & ean Maximun & pular Length \\
\hline
\end{tabular}

In present study the mean vertical diameter of glenoid cavity was $36.09 \pm 2.52 \mathrm{~mm}$ on right and $36.40 \pm 1.86 \mathrm{~mm}$ on left side. In 2015 Wael Amin NED et al ${ }^{17}$ studied 160 with 38.88 $\pm 2.63 \mathrm{~mm}$ vertical diameter on right side and $39.01 \pm 2.49 \mathrm{~mm}$ on left side and Neeta et al $^{18}$ studied 126 scapula in which they reported the vertical diameter of the glenoid cavity $38.46 \pm$ $2.81 \mathrm{~mm}$ on right $(\mathrm{n}=55)$ and $39.03 \pm 3.18 \mathrm{~mm}$ on left $(\mathrm{n}=71)$ which is more than what reported in the present study while this measurement is less in the study by Patil GV et al ${ }^{19}$ who reported $33.68 \pm 4.32 \mathrm{~mm}$ on right $(\mathrm{n}=104)$ and $32.09 \pm 4.11$ $\mathrm{mm}$ on left $(\mathrm{n}=120)$ and Mamatha et al ${ }^{10}$ i.e. $33.67 \pm 2.82 \mathrm{~mm}$ in right scapulae $(\mathrm{n}=98)$ and $33.92 \pm 2.87 \mathrm{~mm}$ in left scapulae $(n=104)$. The ethnic difference may be the reason for the difference in the findings. In this present study, the difference in the vertical diameter of right and left glenoid cavity was statistically non-significant. The mean vertical diameters of the glenoid cavity were compared with various other studies by various authors. Rajput et $\mathrm{al}^{9}{ }^{9}$ measured in the right side was $34.76 \pm 3.0 \mathrm{~mm}$ and in left side was $34.43 \pm 3.21 \mathrm{~mm}$. Sarwar et $\mathrm{al}^{20}$ with sample size 100 came up with findings i.e. on right side $35.22 \pm 3.26 \mathrm{~mm}$ and $34.53 \pm 3.21 \mathrm{~mm}$ on left which was near similar as reported by Pranoti Sinha et al ${ }^{21}(\mathrm{n}=$ 51) reported $33.64 \pm 3.01 \mathrm{~mm}$ and $34.44 \pm 3.27 \mathrm{~mm}$ on right and left scapulae respectively. Churchill et al ${ }^{4}$ Frutos LR, ${ }^{22}$ Ozer et $\mathrm{l}^{23}$ studied vertical diameters of glenoid cavity in males and females. (Table 4)

\section{Transverse Glenoid Diameter- I (TGD-I)}

In present study the mean Transverse Glenoid Diameter I (TGD I) was $24.40 \pm 3.67 \mathrm{~mm}$ and $23.57 \pm 3.41 \mathrm{~mm}$ on right and left side respectively with statistically nonsignificant difference between two sides. Findings of this study were similar to those reported by Mamatha et al, ${ }^{10}$ Rajput HB et al. ${ }^{9}$ Kavitha et $\mathrm{al}^{24}$ Neeta et $\mathrm{al}^{18}$ Sarwar et $\mathrm{al}^{20}$, Pranoti Sinha et al, ${ }^{21}$ Md. Jawed Akhtar et al. ${ }^{13}$ Churchill et $\mathrm{al}^{4}$ recorded mean Transverse glenoid diameter I of $23.6 \pm 1.5 \mathrm{~mm}$ in female scapulae which was very close to our findings. Reported findings Churchill et al, ${ }^{4}$ Frutos LR, ${ }^{22}$ Ozer et al ${ }^{23}$ showed difference in male and female i.e. smaller in females than males. (Table 4)

\section{Transverse Glenoid Diameter -II (TGD-II)}

The mean Transverse Glenoid Diameter -II in this study was $16.02 \pm 2.94 \mathrm{~mm}$ on right side and $16.37 \pm 3.35 \mathrm{~mm}$ on left side.
These differences of right and left sides were also not significant statistically. Values lower than our study were reported by Rajput HB et al. ${ }^{9}$ Our results are similar to Mamatha et $\mathrm{al}^{10}{ }^{10}$ Kavitha et $\mathrm{al}^{, 24}$ Patil GV et $\mathrm{al}^{19}$, Sarwar et $\mathrm{al}^{20}$, Md. Jawed Akhtar et al $^{13}$ but the findings of Neeta et al ${ }^{18}$ i.e. on right side $18.70 \pm 2.22 \mathrm{~mm}$ and $18.6 \pm 2.07 \mathrm{~mm}$ on left side are comparatively higher and the findings by Wael Amin NED et $\mathrm{al}^{17}$ (2015) is highest amongst all i.e. $28.31 \pm 2.38 \mathrm{~mm}$ of right and $27.99 \pm 2.55 \mathrm{~mm}$ of left glenoid. (Table 4 )

\begin{tabular}{|c|c|c|c|c|}
\hline Researcher & Sample Size & VGD & TGD1 & TGDII \\
\hline \multirow{2}{*}{$\begin{array}{l}\text { Churchill et al } \\
\text { (2001) }\end{array}$} & Male: 200 & $37.5 \pm 2.2$ & $27.86 \pm 1.6$ & -- \\
\hline & Female: 144 & $32.6 \pm 1.8$ & $23.6 \pm 1.5$ & -- \\
\hline \multirow{2}{*}{$\begin{array}{l}\text { Frutos LR } \\
\quad(2002)\end{array}$} & Male: 65 & $36.08 \pm 2.0$ & $26.3 \pm 1.5$ & -- \\
\hline & Female: 38 & $31.7 \pm 1.7$ & $22.31 \pm 1.4$ & 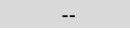 \\
\hline \multirow{2}{*}{$\begin{array}{l}\text { Ozer et al } \\
(2006)\end{array}$} & Male: 94 & $38.71 \pm 2.71$ & $27.33 \pm 2.4$ & 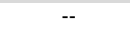 \\
\hline & Female: 92 & $33.79 \pm 3.08$ & $22.72 \pm 1.72$ & -- \\
\hline \multirow{2}{*}{$\begin{array}{l}\text { Mamatha et al }{ }^{10} \\
\qquad(2011)\end{array}$} & Right-98 & $33.67 \pm 2.82$ & $23.35 \pm 2.04$ & $16.27 \pm 2.01$ \\
\hline & Left- & $33.92 \pm 2.87$ & $23.05 \pm 2.30$ & $15.77 \pm 1.96$ \\
\hline \multirow{2}{*}{ Rajput HB et al ${ }^{9}$ (2012) } & Righ & $34.76 \pm 3.0$ & $23.31 \pm 3.0$ & $0 \pm 2.54$ \\
\hline & Left & $34.43 \pm 3.21$ & $22.92 \pm 2.80$ & $13.83 \pm 2.45$ \\
\hline \multirow{2}{*}{$\begin{array}{l}\text { Kavitha et } \text { al }^{24} \\
\text { (2013) }\end{array}$} & Right-67 & $35.2 \pm 3.0$ & $25.07 \pm 2.7$ & $16.8 \pm 1.3$ \\
\hline & Lef & $34.7 \pm 2.8$ & 2.0 & $16.3 \pm 2.0$ \\
\hline \multirow{2}{*}{$\begin{array}{l}\text { Patil GV et al }{ }^{19} \\
\qquad(2014)\end{array}$} & Right: & $33.68 \pm 4.32$ & $23.29 \pm 2.34$ & $15.74 \pm 1.75$ \\
\hline & Left: 120 & $32.09 \pm 4.11$ & $24.90 \pm 2.95$ & $16.81 \pm 1.74$ \\
\hline \multirow{2}{*}{$\begin{array}{l}\text { Neeta et al }{ }^{18} \\
(2015)\end{array}$} & Right-55 & $38.46 \pm 2.81$ & $25.04 \pm 2.69$ & $18.70 \pm 2.22$ \\
\hline & $\mathrm{L}$ & $39.03 \pm 3.18$ & $24.85 \pm 2.46$ & $18.6 \pm 2.07$ \\
\hline \multirow{2}{*}{$\begin{array}{l}\text { Wael Amin NED } \\
\text { et } \mathrm{al}^{17}(2015)\end{array}$} & Right: 80 & $38.88 \pm 2.63$ & $21.33 \pm 2.49$ & $28.31 \pm 2.38$ \\
\hline & Left: 80 & $39.01 \pm 2.49$ & $21.69 \pm 2.06$ & $27.99 \pm 2.55$ \\
\hline \multirow{2}{*}{$\begin{array}{l}\text { Sarwar et al }{ }^{20} \\
\quad(2015)\end{array}$} & Right: 50 & $35.22 \pm 3.26$ & $23.95 \pm 2.78$ & $16.16 \pm 2.38$ \\
\hline & & $34.53 \pm 3.21$ & $23.64 \pm 2.37$ & $15.34 \pm 2.17$ \\
\hline \multirow{2}{*}{$\begin{array}{l}\text { Pranoti Sinha } \\
\text { et } \mathrm{al}^{21}(2016)\end{array}$} & Right-21 & $33.64 \pm 3.01$ & $23.22 \pm 2.85$ & $18.07 \pm 2.64$ \\
\hline & Left- 32 & $34.44 \pm 3.27$ & $23.31 \pm 3.12$ & $18.01 \pm 2.56$ \\
\hline \multirow{2}{*}{$\begin{array}{l}\text { Md. Jawed Akhtar } \\
\text { et } \mathrm{al}^{13}(2016)\end{array}$} & Right: 126 & $36.03 \pm 3.15$ & $23.67 \pm 2.53$ & $16.30 \pm 2.16$ \\
\hline & & & $23.59 \pm 2.47$ & \\
\hline \multirow{2}{*}{$\begin{array}{l}\text { Present study } \\
\quad(2020)\end{array}$} & Right-62 & $36.09 \pm 2.52$ & $24.40 \pm 3.67$ & $16.02 \pm 2.94$ \\
\hline & Left- 60 & $36.40 \pm 1.86$ & $23.57 \pm 3.41$ & $16.37 \pm 3.35$ \\
\hline \multicolumn{5}{|c|}{$\begin{array}{l}\text { Table 4. Comparison of Mean Vertical, Transverse-I and } \\
\text { Transverse-II Glenoid Diameter by Different Researchers }\end{array}$} \\
\hline
\end{tabular}

\begin{tabular}{|c|c|c|c|c|}
\hline Authors & $\begin{array}{l}\text { Sample } \\
\text { Size }\end{array}$ & $\begin{array}{c}\text { Pear } \\
\text { Shaped }\end{array}$ & $\begin{array}{l}\text { Inverted } \\
\text { Comma }\end{array}$ & Oval \\
\hline \multirow{2}{*}{ Mamatha et al. (2011) } & Right - 98 & 46 & 34 & 20 \\
\hline & Left - 104 & 43 & 33 & 24 \\
\hline \multirow{2}{*}{ Rajput HB et al ${ }^{9}(2012)$} & Right - 43 & 49 & 35 & 16 \\
\hline & Left - 57 & 46 & 39 & 15 \\
\hline \multirow{2}{*}{ Kavitha et al ${ }^{24}(2013)$} & Right - 67 & 58 & 30 & 11 \\
\hline & Left - 62 & 58 & 30 & 11 \\
\hline \multirow{2}{*}{ Gamal Hamed ESH ${ }^{25}$ (2015) } & Right - 38 & 44.74 & 31.58 & 23.68 \\
\hline & Left - 30 & 46.67 & 30 & 23.33 \\
\hline \multirow{2}{*}{ Neeta et al ${ }^{18}(2015)$} & Right - 55 & 47 & 31 & 22 \\
\hline & Left - 71 & 55 & 32 & 13 \\
\hline \multirow{2}{*}{ Sarwar et al ${ }^{20}(2015)$} & Right - 50 & 56 & 24 & 20 \\
\hline & Left - 50 & 64 & 20 & 16 \\
\hline \multirow{2}{*}{ Pranoti Sinha et al ${ }^{21}$ (2016) } & Right - 21 & 23 & 08 & 9 \\
\hline & Left - 32 & 42 & 13 & 6 \\
\hline \multirow{2}{*}{$\begin{array}{l}\text { Md. Jawed Akhtar et al }{ }^{13} \\
(2016)\end{array}$} & Right - 126 & 51.59 & 34.92 & 13.49 \\
\hline & Left - 102 & 49.02 & 37.25 & 13.73 \\
\hline Present study & Right - 62 & 51.61 & 33.8 & 14.52 \\
\hline (2020) & Left - 60 & 50 & 40 & 10 \\
\hline
\end{tabular}

\section{Shape of Glenoid Cavity}

The most common shape of glenoid cavity recorded in the present study was pear shape $(50.82 \%)$ followed by inverted comma shape $(36.89 \%)$. The least common shape was oval $(12.30 \%)$. The observations regarding shape of glenoid from this study were similar to the results of Md. Jawed Akhtar et al $^{13}$ in which pear shaped glenoid was found in $51.59 \%$ of sample of the right side and $49.02 \%$ of the left side, which was most common type we observed and second most common type was inverted comma which was found 34.92\% in right side and $37.25 \%$ in left side. Reports by Mamatha et al, Rajput HB et $\mathrm{al}^{9}$ Kavitha et $\mathrm{al}^{24}$ Neeta et al ${ }^{18}$ Sarwar et al, ${ }^{20}$ Pranoti Sinha et $\mathrm{al}^{21}$ showed pear shaped glenoid was most common and inverted comma shaped glenoid was second most common type and oval shaped glenoid was least common but 
Wael Amin NED ${ }^{17}$ came up with different findings i.e. comma shaped glenoid as most common and pear shaped glenoid as second commonest type. Other researchers also reported different shapes in different population like German, Turkish and Egyptian. In German population, Prescher et $\mathrm{al}^{8}$ reported pear shaped in $55 \%$ cases and oval shaped in $45 \%$, in Turkish population Coskun et al ${ }^{16}$ observed oval shaped in $72 \%$ and in $28 \%$ pear shaped glenoid while in $1 / 3^{\text {rd }}$ Egyptian population the reason for propensity to Bankart lesion was found to be because of inverted comma shaped glenoid (30.88\%) as reported by Gamal Hamed ESH.

\section{CONCLUSIONS}

The wide variation in glenoid morphology that adds uncertainties in glenoid component placement is a great challenge to shoulder arthroplasty. Knowledge about various shapes and dimensions of the glenoid is very important for designing the glenoid component for clinical applications such as joint surgeries, shoulder joint (glenohumeral) instability and rotator cuff tears management. It is also helpful during evaluation of different pathological conditions like rotator cuff disease, osteochondral defects, and Bankart lesion. As evident from study of various literatures, demographic variation in morphometry of scapulae is known. So, these types of studies may guide the clinician in decision making regarding pathology of glenohumeral joint and designing prosthesis.

Financial or Other Competing Interests: None.

\section{REFERENCES}

[1] Standring S. Pectoral girdle, shoulder region and axilla. In: Standring S, ed. Gray's anatomy: the anatomical basis of clinical practice. $40^{\text {th }}$ edn. Churchill Livingstone 2008:793-6, 803-7.

[2] Johnson D. Pectoral girdle, shoulder region and axilla. In: Standring S, Borley NR, Collins P, et al, eds. Gray's anatomy: the anatomical basis of clinical practice. $40^{\text {th }}$ edn. Churchill Livingstone 2013:791-822.

[3] Prescher A, Klumpen T. The glenoid notch and its relation to the shape of the glenoid cavity of the scapula. J Anat 1997;190(Pt 3):457-60.

[4] Churchill RS, Brems JJ, Kotschi H. Glenoid size, inclination, and version: an anatomic study. J Shoulder Elbow Surg 2001;10(4):327-32.

[5] Fick R. Anatomie der gelenke. In: Von Bardelben K, ed. Handbuch der anatomie des menschen. Bd II, Abt 1, TI 1. Jena: G Fischer 1904.

[6] Datta AK. Bones of upper limb with special co mments. In: Essentials of human anatomy (Superior and Inferior Extremities) Part. III, $4^{\text {th }}$ edn. Kolkata: Current Books International 2009:5-9.

[7] Sinnatamby CS. Last's anatomy: regional and applied. $11^{\text {th }}$ edn. London: Churchill Livingstone 2006:50-52.
[8] Prescher A, Klumpen T. Does the area of the glenoid cavity of the scapula show sexual dimorphism? J Anat 1995;186(Pt 1):223-6.

[9] Rajput HB, Vyas KK, Shroff BD. A study of morphological patterns of the glenoid cavity of scapula. Natl J Med Res 2012;2(4):504-7.

[10] Mamatha T, Pai SR, Murlimanju BV, et al. Morphology of glenoid cavity. Online J health Allied Scs 2011;10(3):7.

[11] Singal G, Rathod H, Patel A, et al. A study of measurements and indices of human scapula at Jamnagar Medical College. Int J Res Med 2013;2(1):65-8.

[12] Krishnaiah M, Nagaraj S, Praveen Kumar M, et al. Study of scapular measurements and scapular indices of Andhra Pradesh region. IOSR Journal of Dental and Medical Sciences 2014;13(6):117-20.

[13] Akhtar J, Kumar B, Fatima N, et al. Morphometric analysis of glenoid cavity of dry scapulae and its role in shoulder prosthesis. Int J Res Med Sci 2016;4(7):2770-6.

[14] Patel SM, Shah MA, Vora RK, et al. Morphometric analysis of scapula to determine sexual dimorphism. Int J Med Public Health 2013;3(3):207-10.

[15] Flower WH, Garson JG. The scapular index as a race character in man. J Anat Physiol 1879;14(Pt 1):13-7.

[16] Coskun N, Karaali K, Cevikol C, et al. Anatomical basics and variations of the scapula in Turkish adults. Saudi Med J 2006;27(9):1320-5.

[17] El-Din WAN, Ali MHM. A morphometric study of the patterns and variations of the acromion and glenoid cavity of the scapulae in Egyptian population. J Clin Diagn Res 2015;9(8):8-11.

[18] Chhabra N, Prakash S, Mishra BK. An anatomical study of glenoid cavity: its importance in shoulder prosthesis. Int J Anat Res 2015;3(3):1419-24.

[19] Patil GV, Kolagi SI, Ramdurg U. Morphometrical study of scapular glenoid cavities. Global Journal of Medical Research: Orthopedics and Musculoskeletal System 2014;14(2):9-14.

[20] Sarwar MS, Diwan CV, Rafe A, et al. A morphometeric study of glenoid cavity of adult human scapula. International Journal of Recent Trends in Science and Technology 2015;15(3):486-90.

[21] Sinha P, Bhutia KL, Tamang B, et al. Morphometric study of glenoid cavity of dry human scapula. Int J Med Res Prof 2016;2(3):86-90.

[22] Frutos LR. Determination of sex from the clavicle and scapula in a Guatemalan contemporary rural indigenous population. Am J Forensic Med Pathol 2002;23(3):284-8.

[23] Ozer I, Katayama K, Sagir M, et al. Sex determination using the scapula in medieval skeletons from East Anatolia. Coll Antropol 2006;30(2):415-9.

[24] Kavita P, Jaskaran S, Geeta. Morphology of coracoids process and glenoid cavity in adult human scapulae. International Journal of Analytical, Pharmaceutical and Biomedical Sciences 2013;2(2):19-22.

[25] Gamal Hamed ESH. Morphometry of glenoid fossa in adult Egyptian scapulae. Int J Anat Res 2015;3(2):1138-42. 